\title{
Pruning Affects the Development of Correlative Phenomena among Lateral Shoots in Dormant Two-year-old 'Royal Gala' Apple Branches
}

\author{
Paul J.R. Cronjé, Gerard Jacobs, and Nigel C. Cook ${ }^{\mathbf{1}}$ \\ Department of Horticultural Science, University of Stellenbosch, Private Bag \\ X1, Matieland, 7602, South Africa
}

Additional index words. Malus $\times$ sylvestris (L.) Mill. var. domestica (Borkh.) Mansf., paradormancy, dominance, fruit size

\begin{abstract}
Two-year-old apple branches, $\approx \mathbf{5 0} \mathrm{cm}$ long, were selected from a commercial ' $R$ Royal Gala' orchard in the Ceres (Koue Bokkeveld) region of the Western Cape, South Africa [33 ${ }^{\circ} \mathrm{S}, 945 \mathrm{~m}, 1500 \mathrm{Utah}$ model chilling units (CU)]. In 2000, the branches received either cold storage at 5 to $7{ }^{\circ} \mathrm{C}$ or natural chilling in the field. In 2001, the trial was repeated, but only with field chilling. The branches received five dormant pruning treatments: control (not pruned); pruning back to the fourth lateral shoot (heading) before or after chilling; and removal of the second and third lateral shoots (thinning) before or after chilling. After pruning and chilling, the branches were removed from the orchard or cold room every 2 weeks and forced in a growth chamber at $25^{\circ} \mathrm{C}$. The rate of budburst (1/days to budburst) was determined for the terminal buds of the lateral shoots. Lateral shoots on the 2-year-old branches were categorized according to position: the most distal extension shoot, and all other laterals grouped. Removing distal tissue by pruning (heading more than thinning) enhanced the effect of chilling on the terminal buds on the lateral shoots and promoted budburst. Pruning was more effective before than after chilling. Pruning enhanced the growth potential of the terminal buds on proximal shoots on 2-year-old branches.
\end{abstract}

Small size in 'Royal Gala' apples can be a problem, especially under South African conditions. The cause of this costly problem resides mainly in the long growing season, combined with a short and insufficiently cold winter that disrupts the progression of dormancy, negatively influencing branching and tree structure (Cook and Jacobs, 2000). Acrotonic branching is impeded by a modified budburst pattern known as delayed foliation, which involves a protracted opening of buds among and within individual shoots (Cook et al., 1998; Cook and Jacobs, 1999; Saure, 1985). Fewer buds burst, resulting in less, but more autonomous shoots that compete with other shoots and fruits (Cook and Jacobs, 1999; Saunders et al., 1991; Watson, 1986). This problem is managed to some extent by winter pruning. Heading and thinning cuts enhance fruit size. Thinning out competing (thick) laterals on the fruiting branches increased fruit size by $8 \%$, whereas combining thinning plus heading of the weaker spur-bearing laterals increased fruit size by $20 \%$ (Cook and Strydom, 2000). This increase is thought to be the result not only of fruit thinning but also of the fruit being in a dominant position within the fruiting branch (Lombard, 2000).

'Royal Gala' apple trees bear fruit mainly terminally on spurs 2-year-old and older wood. 'Royal Gala' exhibits a tendency for alternation at the spur level, and many of the spurs on a branch are vegetative in any one year (Lauri and Lespinasse, 1993; Lauri and Térouanne,

Received for publication 16 Apr. 2003. Accepted for publication 6 Oct. 2003.

'Corresponding author; e-mail nc@sun.ac.za.
1998; Lauri et al., 1995). In terms of lateral spur autonomy, 'Royal Gala' is classified intermediate between regular bearing cultivars, like 'Granny Smith', and biennial bearing ones, like 'Red Delicious' (Lauri et al., 1995). Fruiting branch architecture in apple and pear has been described by Lauri et al. (1995) and Du Plooy et al. (2002).

Fruiting branches develop over a number of years. Initially, however, following sufficient chilling laterals develop on 1-year-old shoots following proleptic (after dormancy) budburst of the terminal and lateral buds (Cook and Jacobs, 1999). Budburst and branching are acrotonic, i.e., extension shoots form from the most distal buds (Rauh, 1939). Acrotony develops from the ability of the terminal bud to exert dominance over proximally located buds during dormancy (Cook and Bellstedt, 2001; Cook et al., 1998). Acrotony is maintained over a number of years until fruiting eventually checks extension growth.

Yield and fruit quality are influenced by branching habit yet the development of the correlative phenomena that regulate growth in branches are poorly understood. In this communication we report on the effects of pruning manipulations on the development, during dormancy, of correlative phenomena between shoots in apple branches.

\section{Materials and Methods}

Two-year-old branches, $\approx 50 \mathrm{~cm}$ long with at least 10 laterals, were randomly selected from the midcanopy position of 400 'Royal Gala' apple trees in a 5-year-old commercial orchard in the moderately cold Koue Bokkeveld region $\left(33^{\circ} \mathrm{S}, 945 \mathrm{~m}, 1500 \mathrm{CU}\right)$, near Ceres in the Western Cape, South Africa. Data were collected during two consecutive winters. In 2000 the shoots received either natural chilling in the orchard, or artificial chilling in a cold room at 5 to $7^{\circ} \mathrm{C}$. In 2001 the shoots received only natural chilling. Branches for the field chilling trial in 2000 were tagged at the beginning of winter on 8 June. The 2001 trial commenced on 26 Mar. to observe the entrance into endodormancy in fall and the exit in winter. Branches selected for artificial chilling in 2000 were cut from the trees 8 June and immediately transferred to the cold room where they were stored with their bases in water in plastic buckets. Every 2 weeks, six single branch replications per treatment were either cut from the trees (field chilling) or removed from the cold room. The branches were placed into 5 - $\mathrm{L}$ white plastic buckets with their bases in $1 \mathrm{~L}$ of water containing $5 \mathrm{~mL} \cdot \mathrm{L}^{-1}$ household bleach (5\% sodium hypochlorite) and transferred to a growth chamber that was maintained at a constant temperature of $25^{\circ} \mathrm{C}$ and $215 \mu \mathrm{mol} \cdot \mathrm{m}^{-2} \cdot \mathrm{s}^{-1}$ photosynthetically active radiation. During cold storage and forcing the water in the buckets was replaced three times a week and the basal $0.5 \mathrm{~cm}$ of each branch was removed weekly to avoid restriction of water uptake.

For each chilling trial the branches received five dormant pruning treatments: control (not pruned); pruning back to the fourth 1-year-old lateral shoot (heading) before or after chilling; and removal of the second and third lateral shoots (thinning) before or after chilling (Fig. 1). Lateral 1-year-old shoots on the 2-year-old branches were numbered from the terminal (position one). When necessary, the most proximal

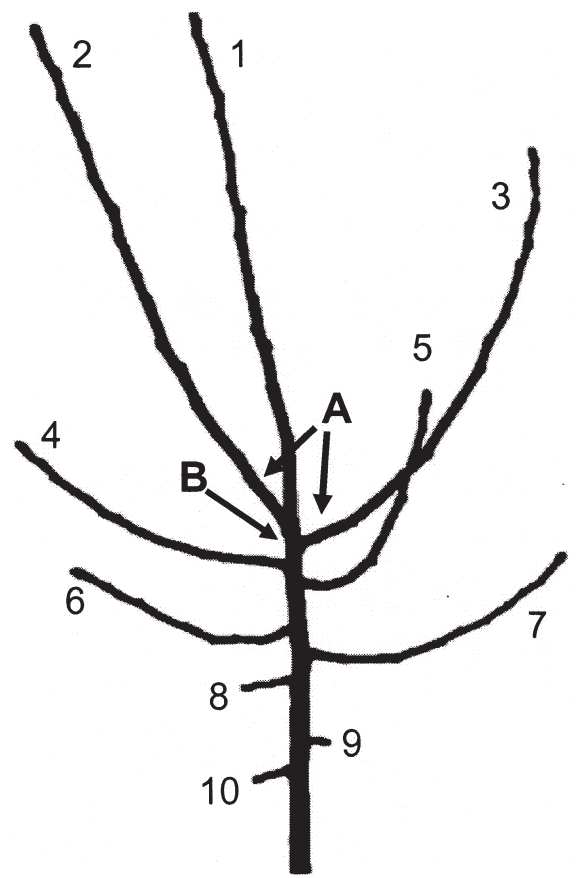

Fig. 1. Diagrammatic representation of the pruning treatments conducted on dormant 2-year-old 'Royal Gala' apple branches. Numbers indicate shoot position. Arrows indicate the position of the thinning (A) and heading (B) cuts. 
laterals were removed, leaving the 10 most distal ones. The pattern of budburst was recorded for each lateral every 2 to $3 \mathrm{~d}$ (up to $90 \mathrm{~d}$ ) until the terminal buds on all ten laterals had either burst (defined as the first visible signs of green or green tip) or died.

Initially two classes of lateral shoot position on the branch were identified: the most distal shoot (position one in the control and thinning treatments, position four in the heading treatments); and all laterals grouped (positions two to ten in the control, positions four to ten in the thinning and heading treatments). The rate of budburst was compared between these two positions within each pruning treatment. In a subsequent analysis the rate of budburst of the lateral in position four was compared between the pruning treatments. The rate of budburst was calculated as (1/days to budburst) as described by Cannell (1989). Changes in the rate of budburst were compared by analysis of variance using the general linear models procedure of SAS version 6.12 (SAS Institute, Cary, N.C.). In both years budburst in the field was observed by mid-September.

\section{Results and Discussion}

The change in rate of terminal budburst on laterals in different positions along the 2year-old axis is presented (Figs. 2 and 3). The increased rate of budburst, i.e., the exit from dormancy, was clearly observed in both years. In 2001, the rate of budburst initially decreased as the buds entered dormancy in fall. Chilling in the cold room was more effective than chilling in the field (Figs. 2 and 3). In the control treatments no difference in rate of budburst was observed between the terminal and the lateral shoots (Fig. 2 , Table 1). Thinning tended to increase the rate of budburst on the remaining proximally situated laterals, particularly thinning before chilling in the field 2000. Heading before chilling allowed the most distal lateral (in position four) to assume dominance. Response to removal of distal shoot tissues differed depending on timing; pruning before chilling was more effective. This was most evident comparing heading before and after chilling.

All pruning treatments in all three trials stimulated the growth of the most distal (fourth) lateral (Table 2, Fig. 3). With heading before chilling the distal lateral also exhibited dominance over the proximal laterals (Fig. 2), even at 5 to $7{ }^{\circ} \mathrm{C}$, temperatures believed to inhibit auxin transport (Morris, 1979). These results not only indicate the presence of correlative inhibition on budburst on subtending laterals, acting in a basipetal direction and removed by pruning, but also that this mechanism can function during chilling.

Auxin (indoleacetic acid) is believed to play a central role in correlative effects like apical dominance and apical control (Bangerth, 1989; Cline, 1997; Cline and Deppong, 1999; Cline et al., 1997). Bangerth et al. (2000) suggested how auxin transport auto inhibition could be responsible for correlative inhibitions, such as apical dominance, paradormancy and primegenic dominance. These researchers found this auxin-driven mechanism sufficient

Cold storage 2000

Field 2000

Field 2001

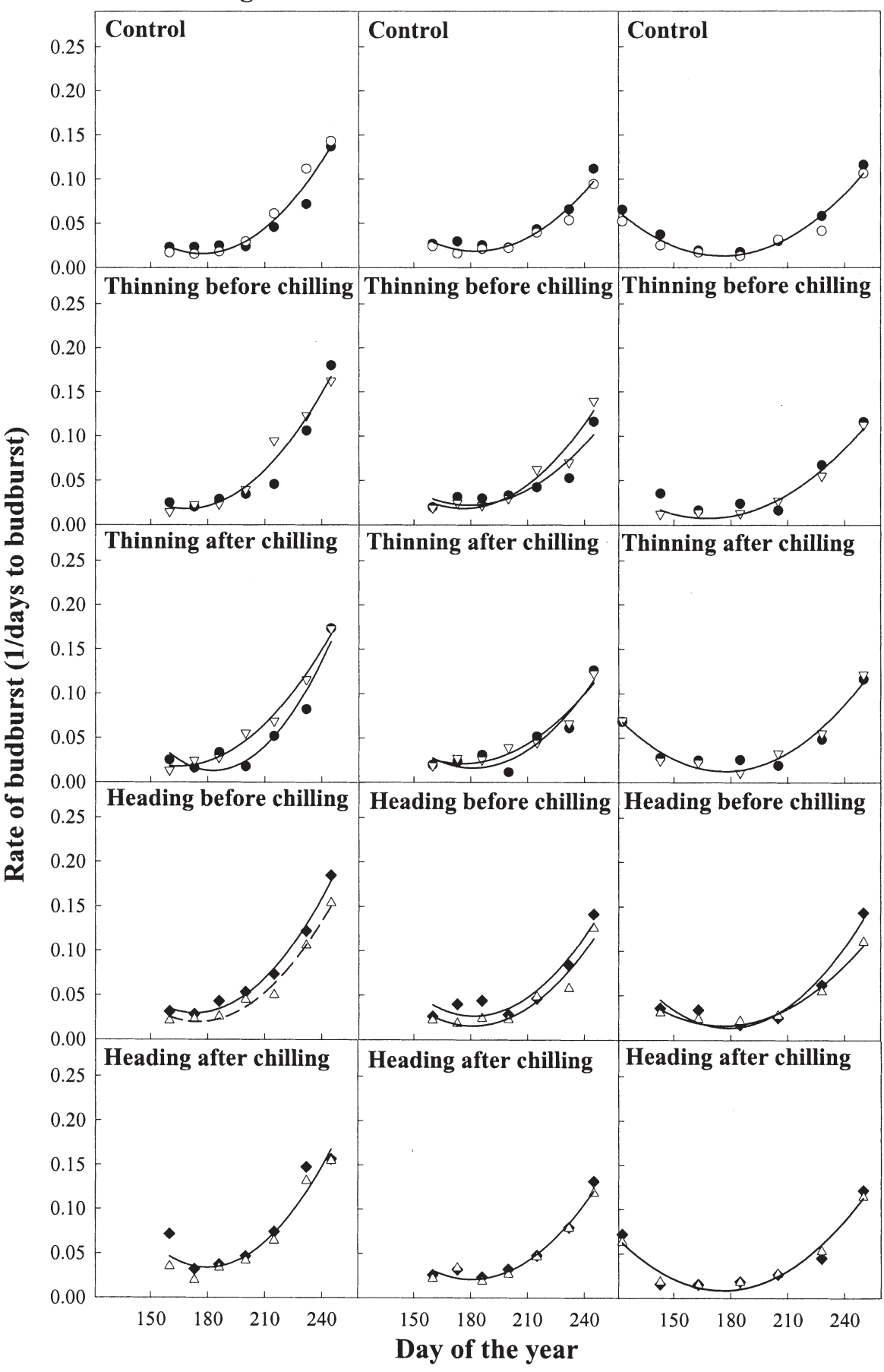

Fig. 2. The change in rate of budburst on distal and proximal shoots, on dormant 2-year-old 'Royal Gala' branches chilled in cold storage at 5 to $7{ }^{\circ} \mathrm{C}$ or in the field. The lateral shoots on each branch were classified into two positions and compared within each pruning treatment: 1) the most distal shoot [the terminal in the control and thinning treatments $(\bullet)$, the lateral in position four in the heading treatments $(\diamond)$ ]; and 2) all proximal laterals grouped [positions two to ten in the control $(\bigcirc)$, positions four to ten in the thinning treatments $(\Delta)$, positions five to ten in the heading treatments $(\nabla)]$. Where no significant difference was detected at the $10 \%$ level between the distal and proximal positions only a single trend line is presented.

to impose dominance without the need for other regulatory effects. Once the distal inhibition is removed, either totally by heading or partially by thinning, a lateral can become autonomous in its response to environmental signals like chilling (Fig. 3). The concept of an autonomous unit, consisting of physiological and/or morphological subunits, has been extended to include assimilation, distribution and use of carbon, and patterns of transport and utilization of mineral nutrients and hormones (Watson, 1986).

Cook and Bellstedt (2001) have previously shown in 1-year-old apple shoots that the isolation of lateral buds from distal inhibition by decapitation during chilling (dormancy) increases the growth potential of these buds. Distal shoot tissues inhibit the normal chilling 


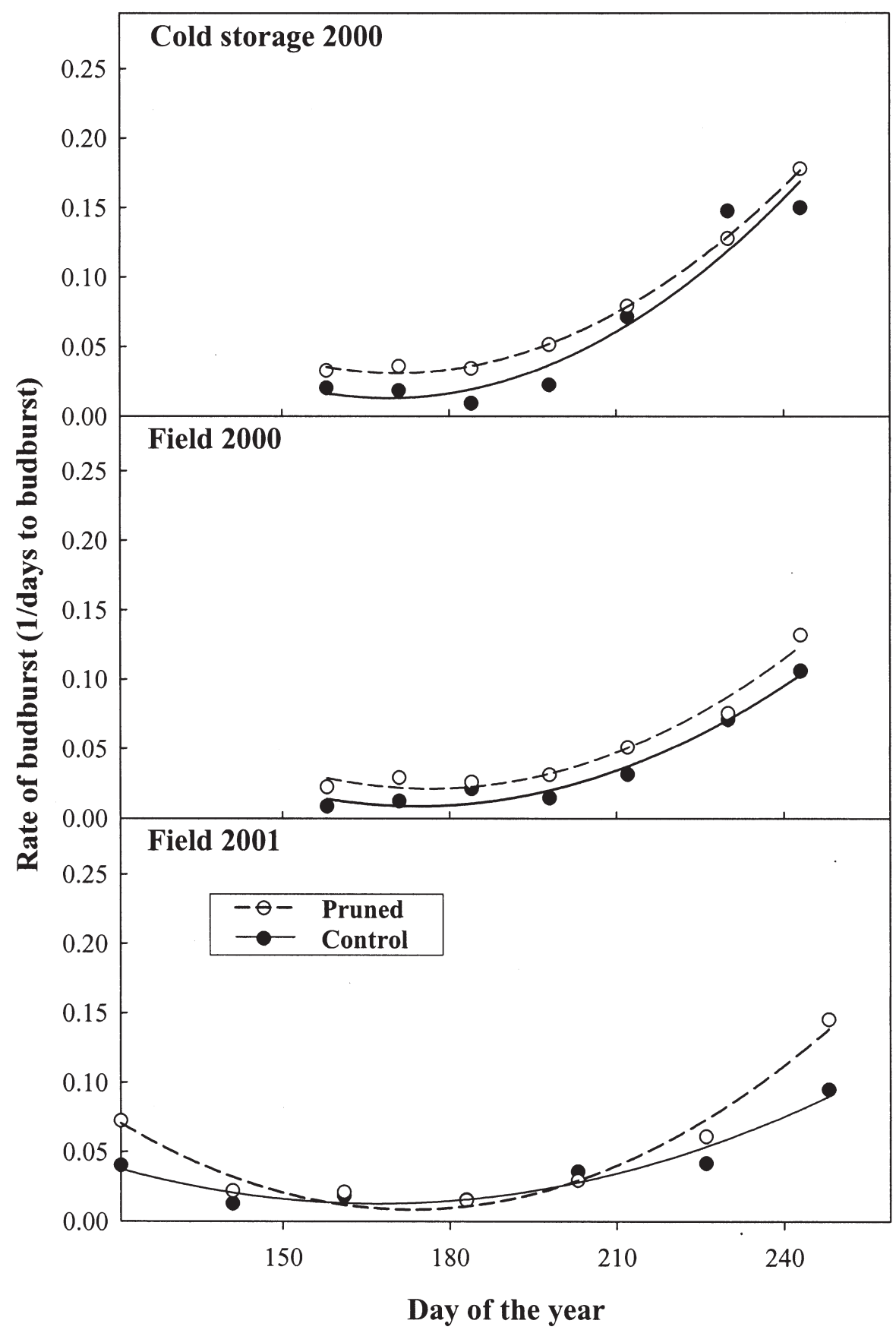

Fig. 3. The effect of pruning on the change in the rate of budburst of the terminal bud on the most distal lateral shoot (position four) on dormant 2-year-old 'Royal Gala' branches chilled in cold storage at 5 to $7{ }^{\circ} \mathrm{C}$ or in the field. The pooled means of the pruning treatments are presented. Statistical analyses as in Table 2.

response (increased growth rate) of lateral buds on 1-year-old shoots or, as shown in these data, terminal buds on subtending lateral branches. The results presented here in terms of increased growth potential during and after dormancy, as well as the significant increase in fruit size realized through these pruning techniques (Cook and Strydom, 2000; Lombard, 2000), further support the reasoning that once a shoot is released from correlative inhibition or paradormancy within the branch system, it becomes more autonomous through an improved response to chilling. This autonomy results in earlier budburst and the ability to exert dominance. Once dominant, an increased allocation of assimilates could possibly lead to increased fruit growth and higher yields due to being a more competitive sink. 
Table 1. The significance levels $(P>\mathrm{F})$ of the comparative analyses of the change in rate of budburst between distal and proximal shoots, on dormant 2-year-old 'Royal Gala' branches chilled in cold storage at 5 to $7{ }^{\circ} \mathrm{C}$ or in the field. The lateral shoots on each branch were classified into two positions and compared by analysis of variance within each pruning treatment: 1) the most distal shoot (the terminal in the control and thinning treatments, the lateral in position four in the heading treatments); and 2) all proximal laterals grouped (positions two to ten in the control, positions five to ten in the thinning and heading treatments). The results of the analyses are shown in Fig. 2.

\begin{tabular}{|c|c|c|c|c|}
\hline $\begin{array}{l}\text { Pruning } \\
\text { treatment }\end{array}$ & $\begin{array}{l}\text { Class } \\
\text { variable }\end{array}$ & $\begin{array}{c}\text { Cold } \\
\text { storage } \\
2000\end{array}$ & $\begin{array}{l}\text { Field } \\
2000\end{array}$ & $\begin{array}{l}\text { Field } \\
2001\end{array}$ \\
\hline \multicolumn{5}{|l|}{ Control } \\
\hline & Position & 0.2081 & 0.1615 & 0.1417 \\
\hline & Time & 0.0001 & 0.0010 & 0.0001 \\
\hline & Position $\times$ time & 0.1853 & 0.7181 & 0.0924 \\
\hline \multicolumn{5}{|c|}{ Thinning before chilling } \\
\hline & Position & 0.4350 & 0.0688 & 0.9170 \\
\hline & Time & 0.0001 & 0.0001 & 0.0001 \\
\hline & Position $\times$ time & 0.1318 & 0.0438 & 0.2362 \\
\hline \multicolumn{5}{|c|}{ Thinning after chilling } \\
\hline & Position & 0.0862 & 0.0292 & 0.5335 \\
\hline & Time & 0.0001 & 0.0001 & 0.0001 \\
\hline & Position $\times$ time & 0.0562 & 0.3711 & 0.3875 \\
\hline \multicolumn{5}{|c|}{ Heading before chilling } \\
\hline & Position & 0.0075 & 0.0035 & 0.0527 \\
\hline & Time & 0.0010 & 0.0010 & 0.0001 \\
\hline & Position $\times$ time & 0.9084 & 0.5791 & 0.1125 \\
\hline \multicolumn{5}{|c|}{ Heading after chilling } \\
\hline & Position & 0.1226 & 0.2728 & 0.6586 \\
\hline & Time & 0.0001 & 0.0010 & 0.0001 \\
\hline & Position $\times$ time & 0.9217 & 0.9763 & 0.6362 \\
\hline
\end{tabular}

Table 2. The effect of time and type of pruning treatment on the rate of budburst of the terminal bud on shoots in the fourth lateral position on dormant 2-year-old 'Royal Gala' branches chilled in cold storage at 5 to $7^{\circ} \mathrm{C}$ or in the field.

\begin{tabular}{|c|c|c|c|}
\hline \multirow{2}{*}{$\begin{array}{l}\text { Pruning } \\
\text { treatment }\end{array}$} & $\begin{array}{c}\text { Cold } \\
\text { storage } \\
2000\end{array}$ & $\begin{array}{l}\text { Field } \\
2000\end{array}$ & $\begin{array}{l}\text { Field } \\
2001\end{array}$ \\
\hline & \multicolumn{3}{|c|}{ (1/days to budburst) } \\
\hline Control & 0.037 & 0.038 & 0.066 \\
\hline Heading before chilling & 0.053 & 0.052 & 0.073 \\
\hline Heading after chilling & 0.051 & 0.051 & 0.072 \\
\hline Thinning before chilling & 0.058 & 0.054 & 0.077 \\
\hline Thinning after chilling & 0.047 & 0.052 & 0.081 \\
\hline \multicolumn{4}{|l|}{ Significance $(P>\mathrm{F})$} \\
\hline Pruning treatment & 0.2901 & 0.0060 & 0.2040 \\
\hline Time & 0.0001 & 0.0001 & 0.0001 \\
\hline Pruning treatment $\times$ time & 0.0530 & 0.9590 & 0.3566 \\
\hline Control vs. pruned & 0.0083 & 0.0044 & 0.0352 \\
\hline Heading vs. thinning & 0.2650 & 0.2590 & 0.5691 \\
\hline Heading before vs. heading after & 0.2231 & 0.8244 & 0.3730 \\
\hline Thinning before vs. thinning after & 0.2833 & 0.4273 & 0.5954 \\
\hline
\end{tabular}

\section{Literature Cited}

Bangerth, F. 1989. Dominance among fruit/sinks and the search for a correlative signal. Physiol. Plant. 76:608-614.

Bangerth, F., C.-J. Li, and J. Gruber. 2000. Mutual interaction of auxin and cytokinins in regulating correlative dominance. Plant Growth Regulat. $32: 205-217$
$155: 350-356$.

Cline, M.G., T. Wessel, and H. Iwamura. 1997. Cytokinin/auxin control of apical dominance in Ipomoea nil. Plant Cell Physiol. 38:659-667.

Cook, N.C. and D.U. Bellstedt. 2001. Chilling response of 'Granny Smith' apple lateral buds inhibited by distal shoot tissues. Scientia Hort. 89:299-308.

Cook, N.C. and G. Jacobs. 1999. Suboptimal winter chilling impedes development of acrotony in apple shoots. HortScience 34:1213-1216.

Cook, N.C. and G. Jacobs. 2000. Progression of apple (Malus $\times$ domestica Borkh.) bud dormancy in two mild winter climates. J. Hort. Sci. Biotechnol. 75:233-236

Cook, N.C., E. Rabe, J. Keulemans, and G. Jacobs. 1998. The expression of acrotony in deciduous fruit trees: A study of the apple rootstock M.9. J. Amer. Soc. Hort. Sci. 123:30-34.

Cook, N.C. and D.K. Strydom. 2000. The South African high-density system. Acta Hort. 513:321-327.

Du Plooy, P., G. Jacobs, and N.C. Cook. 2002. Quantification of bearing habit on the basis of lateral bud growth of seven pear cultivars grown under conditions of inadequate winter chilling in South Africa. Scientia Hort. 95:185-192.

Lauri, P.E. and J. M. Lespinasse. 1993. The relationship between cultivar fruiting-type and fruiting branch characteristics in apple trees. Acta Hort. 349:259-263.

Lauri, P.E. and E. Tèrouanne. 1998. The influence of shoot growth on the pattern off axillary development on the long shoots of young apple trees (Malus domestica Borkh.). Intl. J. Plant Sci. 159:283-296.

Lauri, P.E., E. Tèrouanne, J.M. Lespinasse, J-L. Regnard, and J-J. Keller. 1995. Genotypic differences in the axillary bud growth and fruiting pattern of apple fruiting branches over several years-An approach to regulation of fruit bearing. Scientia Hort. 64:265-281.

Lombard, C. 2000. Fruit size improvement of 'Royal Gala' apples. MS thesis. Univ. Stellenbosch, South Africa.

Morris, D.A. 1979. The effect of temperature on the velocity of exogenous auxin transport in intact chilling-sensitive and chilling-resistant plants. Planta 146:603-605.

Rauh, W. 1939. Über Gesetzmäßigkeit der Verzweigung und deren Bedeutung für die Wuchsformen der Pflanzen. Mitt. Dtsch. Dendr. Ges. 52:86-111.

Saunders, R.C., G. Jacobs, and D.K. Strydom. 1991. Effect of pruning on fruitset and shoot growth of 'Packham's Triumph' pear trees. Scientia Hort. 47:239-245.

Saure, M. 1985. Dormancy release in deciduous fruit trees. Hort. Rev. 7:239-300.

Watson, M.A. 1986. Integrated physiological units in plants. Tree 1:119-123. 